\title{
Assemblage Thinking and the City: Implications for Urban Studies
}

\author{
Hesam Kamalipour, Nastaran Peimani \\ Faculty of Architecture, Building and Planning, University of Melbourne, Melbourne, Australia \\ Email: hesam.kamalipour@unimelb.edu.au
}

Received 25 November 2015; accepted 18 December 2015; published 21 December 2015

Copyright (C) 2015 by authors and Scientific Research Publishing Inc.

This work is licensed under the Creative Commons Attribution International License (CC BY). http://creativecommons.org/licenses/by/4.0/

cC) (i) Open Access

\section{Abstract}

The last decade has seen an increasing interest in the application of assemblage thinking, in geography, sociology, and urban studies. Different interpretations of the Deleuzian concept of assemblage give rise to the multiple articulations of the term in urban studies so far. This paper aims to review the recently published research on assemblage theory and explore the implications of assemblage thinking in urban studies. The study thus provides an overview of the most significant contributions in the area, including a succinct bibliography on the subject. The paper concludes that assemblage can be effectively adopted as a way of thinking in urban studies to provide a theoretical lens for understanding the complexity of the city problems by emphasising the relations between sociality and spatiality at different scales.

\section{Keywords}

Assemblage, Urban Theory, Deleuze, Critical, De Landa, Urbanism

\section{Introduction}

Assemblage is one of the key concepts in the Deleuzian philosophy that has been interpreted, adopted, and understood in different ways within the last decade. Assemblage is related to the notions of apparatus, network, multiplicity, emergence, and indeterminacy, and there is not a simple "correct" way to adopt the term (Anderson \& McFarlane, 2011). Reading Deleuze and Guattari (1987) conception of assemblage, De Landa (2006), as one of the main interpreters of the concept, has critically theorized the multiplicity of assemblage thinking for exploring the complexity of the society. Since then, the concept of assemblage has been adopted in various academic disciplines with different articulations as theoretical and methodological frameworks for exploring the socio-spatial complexities. In urban studies, assemblage thinking has been challenged by various traditions of thinking such as political economy and critical urbanism. Since the 1960s, it has been argued that the city prob- 
lems are often "complex" (Alexander, 1964; Jacobs, 1961) in a way that the outcomes cannot be simply predicted. Reviewing the recently published research on assemblage theory, the paper addresses its implications for urban studies to conclude that assemblage thinking has the capacity to provide theoretical and methodological frameworks for exploring the complexity of the city problems and the processes through which urbanity emerges in relation to intricate socio-spatial networks at multiple scales.

\section{Assemblage Thinking}

The concept of assemblage has been adapted from the work of Deleuze and Guattari (1987) and applies to an extensive variety of wholes like the social entities generated by the heterogeneous parts (De Landa, 2006). The idea of assemblage has been addressed as "agencement" that refers to the process of putting together a mix of relations (Dewsbury, 2011), and in its original French sense refers to "arrangement", "fixing", and "fitting" (Phillips, 2006). Thus, assemblage as a whole refers to the "process" of arranging and organizing and claims for identity, character, and territory (Wise, 2005). Opposed to the "relations of interiority" in the "organic totalities", the "relations of exteriority" are characterizing the assemblages as the wholes (De Landa, 2006). In other words, new identities are generated through connections (Ballantyne, 2007). In this way, as De Landa (2006) argues assemblage as a whole cannot be simply reduced to the aggregate properties of its parts since it is characterised by connections and capacities rather than the properties of the parts (De Landa, 2006). Thus, assemblages include heterogeneous human/non-human, organic/inorganic, and technical/natural elements (Anderson \& McFarlane, 2011). Enabling and constraining its parts, the assemblage is an alliance of various heterogeneous elements (De Landa, 2010). Assemblages are dynamically made and unmade in terms of the two axes of "territorialisation (stabilization)/deterritorialisation (destabilization)" and "language (express)/technology (material)”(Wise, 2005). In a sense, assemblages are at once both express and material (Dovey, 2010). In other words, assemblages focus on both actual/material and possible/emergent (Farías, 2010). Assemblages are fundamentally territorial (Deleuze \& Guattari, 1987) where territorialisation is both spatial and non-spatial (social) (De Landa, 2006). In other words, the territory is a stabilized assemblage (Dovey, 2010). Accentuating the relations and capacities to express and change, orienting towards a kind of experiment-based realism, and rethinking causality and agency, assemblage thinking contributes to the contemporary articulation of social-spatial relations (Anderson, Kearnes, McFarlane, \& Swanton, 2012). In effect, it addresses the inseparability of sociality and spatiality and the ways in which their relations and liaisons are established in the city and urban life (Angelo, 2011). Hence, assemblage theory is against a priori reduction of sociality/spatiality to any fixed forms/set of forms in terms of processes or relations (Anderson \& McFarlane, 2011). Figure 1 illustrates a conception of assemblage in relation to the two axes of express/material and territorialisation/deterritorialisation.

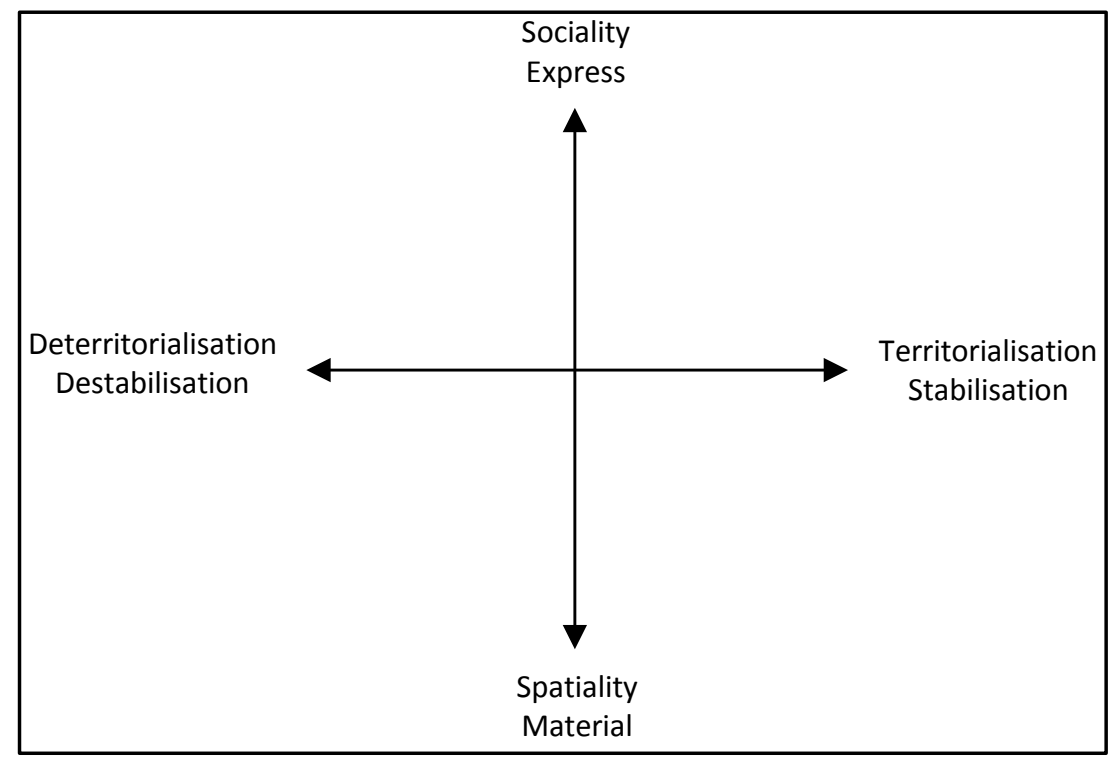

Figure 1. A conception of assemblage based on De Landa (2006). 
Assemblage theory offers a "bottom-up" ontology that works with analytical techniques rather than logical reasoning and refers to the universal singularities instead of reducing individuals to the essentialist myths of the species and natural kinds (De Landa, 2006). It also avoids phenomenological idealism and different types of reductionism, including the reduction to text, essence, social construction, and discourse (Dovey, 2010). Hence, the theory of assemblage opposes the reduction of the entities to the essences as a deficiency of the social realism (De Landa, 2006). While "realist" philosophers refer to the identity of the mind-independent contents as the "essences", Deleuze argues that these identities cannot be ever "taken for granted" since there is always a need for explaining the historical processes of their production (De Landa, 2005). Although the capacity to generate an assemblage is reliant on the emergent properties of the parts, it cannot be simply reduced to them (De Landa, 2002).

Deleuzian conceptions of "dis-order" and "assemblage" stem from his relatively explicit indebtedness to the works of Foucault in terms of the "order" and "apparatus" (Legg, 2011). The concept of apparatus refers to an entirely "heterogeneous ensemble" containing the institutions, discourses, propositions, laws, regulations, and architectural forms (Foucault, 1980). Considering the evolution of the "apparatus” term, Legg (2011) argues that the idea of controlling the human thoughts and behaviours is central to the notion of apparatus. Capturing the continuous presence of "problematisation" in the works of Foucault, Deleuze conceptualises the "assemblage theory" to dissolve the "bordered thinking" of territory, philosophy, and desires (Legg, 2011). Referring to the slippage of Foucault between assemblage and apparatus, Legg (2011) argues that the Foucaultian usage of "assemblage" stems from almost a decade of collaboration with Deleuze (1960s-1970s), and it does not systematically refer to the process of destabilization or deterritorialisation. However, the Deleuzian interpretive conception of "apparatus" is plausibly "assemblage-like" in terms of referring to both stratification and creativity (Legg, 2011).

Assemblage thinking is about relations, heterogeneity, and differences rather than parts, homogeneity, and similarities. There is a distinction here between "diversity" and "difference". Distinguishing between phenomena (appearance) and noumena (in itself), Deleuzian thinking refers to "diversity" as phenomena while it considers "difference" as a noumena (De Landa, 2005). Assemblage thinking is about multiplicities rather than singularities since the concept of "multiplicity/manifold" refers to the ways of change and the "space of possibilities" (De Landa, 2005). In fact, the identity of a whole is defined by its emergent tendencies, capacities, and properties (De Landa, 2011) since the "virtual status of possibility" is "immanent to the material world" rather than being something transcendent (De Landa, 2005). Moreover, assemblages work across multiple scales, and they can be considered as the "abstract machines" expressing a broader set of functions (Wise, 2005). In this way, considering that the existence of some parts is prior to the emergence of a whole while the other parts can be generated by the whole, assemblages are continuously in the process of emerging and becoming, which requires a "multiscale" explanation (De Landa, 2006). In other words, assemblages are constantly in the fluid status of "becoming" rather than "being" (Dovey, 2010). Thus, "becoming" is the process of unfolding the complexity of events in between territorialisation and deterritorialisation of an assemblage (Buchanan \& Parr, 2006).

Assemblage theory offers a broad range of twofold conceptions that resonate with material/express and territorialisation/deterritorialisation. One of the key twofold conceptions is tree-like/rhizomatic. Tree-like structures are hierarchic and rigidly stratified while rhizomatic and meshwork-like ones are often loosely structured. In a sense, rhizomatic structures contribute to the generation of resilient and flexible assemblages as intensive networks of multiplicities with external/internal relations (Bonta \& Protevi, 2004). In other words, the differences between "strata/tree-like" and "rhizome/self-consistent aggregate" are about the articulation of the homogeneous and the heterogeneous elements (De Landa, 2000). Hence, The hierarchical city (central place structure) is distinguishable from the meshwork-like one (network system) since the former gives rise to the rigidified pyramid-like and homogenised cultural structures while the latter advocates for interlocking heterogeneous elements (De Landa, 1997). Nonetheless, the dichotomy of strata and rhizome is a continuum with two ends of the most hierarchic and the most intense and destratified matter (De Landa, 2000). As Dovey (2010) argues, the experience of the everyday urban life encompasses a variety of rhizomatic and hierarchic practices in relation to the public and private spaces. In the same vein, being/becoming is another twofold that resonates with tree/rhizome and striated/smooth in assemblage thinking. The notion of "being" refers to the status of remaining constant as the source or foundation whereas the concept of "becoming" relates to a less substantial changing and ephemeral situation (May, 2005). Suggesting the Deleuzian idea of "becoming-in-the-world" instead of Heideggerian concept of "being-in-the-world", Dovey (2010) cuts across the social-spatial division, and addresses the question of place in relation to spatiality and sociality where spatiality is connected to sociality through the intensity of place 
in everyday urban life.

\section{Assemblage and the City}

Being unfinished, cultural/physical, constitutive, socio-material, subjective/objective, and tricky, the urban areas and cities are ideal models for adopting assemblage thinking (Tonkiss, 2011). Assemblage thinking addresses the city as a "multiplicity" rather than a "whole" (Farías, 2011). In a sense, assemblage refers to the ways in which urbanism is produced not as a "resultant formation", but as an ongoing process of construction (McFarlane, 2011a). Adopting "assemblage thinking” for conceptualizing the city, McFarlane (2011b) argues that assemblage relates to the city as a "verb" in "making urbanism" through historical and potential relations. Thus, an assemblage is the result of the "interactions" between elements rather than the properties of the components and it is defined by the "co-functioning" of the individual elements in terms of stabilizing/destabilizing (McFarlane, 2011b). In a sense, McFarlane (2011b) adopts a political orientation to the assemblage for thinking about the actual/possible relations in the city since assemblage can be considered as both an object regarding the urban policies and orientation in terms of the policy productions. In this way, McFarlane (2011b) argues that the conception of the "city as assemblage" is accompanied by a quest for an entity (who/what) that has the "capacity" for assembling the city. Hence, assemblage refers to the issue of power as "plurality in transformation" rather than being centrally adopted or equally distributed (Anderson \& McFarlane, 2011) since it offers the possibility of holding together the heterogeneous elements, such as the nation state or the regional political formations, without an actual establishment of a coherent whole (Allen, 2011). Being heterogeneous and discontinuous, power regionally and temporarily comes about in distinct, interrelated, and overlapped assemblages (Eriksson, 2005). In a sense, assemblages are the main products of the "flows of desire" as the primary "force of life" and the basis of the productive and positive power (Dovey, 2010). The potential structure of an assemblage has been considered as a capacity for organizing and distributing power (Bell \& Colebrook, 2009) since assemblage process is hierarchically structured through "inequalities of power" and resource (McFarlane, 2011a). McCann (2011) addresses the analytical and political potentials of assemblage for exploring urban politics and the global/ urban connections. For McCann, Roy, and Ward (2013), assemblage thinking is likely to contribute to the conceptualization of the contemporary city in relation to the global condition.

\section{Assemblage and Critical Urbanism}

Although the critical urban theory has been addressed to be capable of contributing to the understanding of the city, the relations between critical urbanism and assemblage thinking is controversial among scholars with different critical stances. Critical urban theory refers to an ongoing process of constructing/reconstructing the city as a medium/result of historical "relations of social power" (Brenner, 2009). Thus, critical urban theory interrogates the existing urban formations and refers to the critique of power, ideology, injustice, exploitation, and inequities in the cities (Brenner, 2009).

Exploring the relations between assemblage and critical urbanism, McFarlane (2011a) adopts assemblage as a concept, orientation, and imaginary where he refers to assemblage as a relational composition process that contributes to the labour and socio-materiality of the city. He reads assemblage as an orientation to the potentiality of actors and sites in relation to the history, required labour, and the capacity of urban processes (McFarlane, 2011b). He further argues that while assemblage concentrates on multiple practices of achieving urbanism in actual/possible relations, it is related to a broader history of critical urbanism (McFarlane, 2011b). Thus, for him, assemblage offers some orientations to "critical urbanism" in terms of focusing on potentiality, agency of materials, and composition of the cosmopolitan imaginary (McFarlane, 2011a). For Tonkiss (2011), assemblage thinking is likely to generate a "template urbanism", rather than a critical one. She argues that since the matters generally facilitate the agency of the people, the "effectivity" of things is not like the human agency (Tonkiss, 2011). Hence, while McFarlane (2011a) argues that assemblage provides a thick description of history/potentiality relations along with the distribution of agency across materiality/sociality, Tonkiss (2011) doubts the relation of the assemblage theory to the interpretation, semiotics, and meaning.

Rejecting the existence of a single "assemblage urbanism" in urban theory, Brenner, Madden, and Wachsmuth (2011) tend to adopt assemblage theory in relation to the political economy rather than addressing assemblage thinking as a basis for the critical urban theory. Moreover, criticizing the adoption of the assemblage theory as an ontology for urban studies in which the position of political economy and concept of capitalism are ambiguous, Brenner et al. (2011) refer to assemblage concept as a methodological practice and outlinethat a 
broad framework of "assemblage-theoretical urbanism” might have impact on its potentiality of analysis. Brenner et al. (2011) further argue that the thick descriptive focus of the assemblage thinking ignores the "context of context" regarding the broader global/national/regional structures.

While Marxian-origin critical urban study tends to adopt city as an "instance" of capitalistic organization in terms of industrial or space production, assemblage thinking does not address capitalism as a "form of life" rather than a global "abstract logic" and proposes an inquiry to the city/urbanization as an actual and ecological process (Farías, 2011). Thus, although Acuto (2011) denotes that the ontological, methodological, and empirical conceptions of the assemblage cannot simply be explored separately from each other, Farías (2011) argues that assemblage thinking tends to develop empirical knowledge rather than theoretical analysis and critique since it involves both agency and arrangement. Hence, assemblage thinking is about inquiry and explorative engagement rather than power/knowledge/ideology-based critique since inquiry quests for an empirical commitment rather than a general theory of the relatively fixed concepts (Farías, 2011). He further denotes that the critique is better to be involved with empirical practices rather than mere general theories (Farías, 2011). Affirming the effects of capital, Simone (2011) argues that detailed inquiries need to be put in place for exploring the particular practices and sites of urbanisation since assemblages have the capacity to generate multiple surfaces that can always be built and erased. Moreover, referring to critical urbanism as an extensive scholarly involvement with processes in which the practices of power are associated with the cities, Dovey (2011) argues that assemblage thinking cannot be simply constrained within the rigid framework of political economy since it has the capacity to critically contribute to the ontologies of place and power.

\section{Implications for Urban Studies}

One of the critical contributions of assemblage thinking for understanding the complexity of the city problems is to encourage multiscalar thinking. A key to understand the urban issues in a given city area is geared to the exploration of the ways that area connects with the urban environments over a range of different scales. Thus, limiting the analysis of an urban environment to a certain scale runs the risk of overlooking the relations to the both larger and smaller scales. Multiscalar thinking as a toolkit can be applied to unravel how urban assemblages work across different scales. Hence, the ways in which socio-spatial multiplicities link at various scales need to be analysed to contribute to the most effective interventions in urban environments. For instance, to improve the access network in a given area, the focus needs to be concentrated on the boundary effect and the ways in which micro, meso, and macro scales are interrelated. In a sense, both theory and practice can benefit from multiscalar thinking since it has the capacity to stimulate integral approaches to planning and design.

The diagram can be understood as an "abstract machine" in Deleuzian concept of assemblage thinking. In this way, diagrammatic thinking can be used as a means to abstractly illustrate the complexities of an urban assemblage as both a product and process. In the same vein, the mapping can be considered as an abstraction that has the capacity to unravel what De Landa (2005) calls "real virtuality", which is a kind of "reality" that has not been "actualised" yet. In effect, not only assemblage thinking puts emphasis on the "thick description" of the relationships that have assembled urban networks in different ways, but also it focuses on the space of possibilities that are associated with the latent capacities. For instance, when it comes to the study of urban morphology, typology can be considered as a process in which types work as the "abstract machines" that have the capacity to illustrate the morphogenesis of the urban form (Kamalipour, Memarian, \& Mousavian, 2012; Kamalipour \& Zaroudi, 2014). In this way, diagrams, maps, and types have the capacity to produce a kind of "spatial knowledge" that can be effectively used as a basis to draw on the ways in which the city works in relation to spatiality and sociality. It also assists with specifying the space of possible solutions for the existing city problems and embodied capacities for transformational change.

Assemblage thinking is against essentialism and reductionism in different ways. While essentialist approaches in urban studies tend to reduce the concept of place to an essence with a stabilised identity (Kamalipour, Faizi, \& Memarian, 2014; Kamalipour, Yeganeh, \& Alalhesabi, 2012), assemblage theory reads place as a multiplicity that is in the process of "becoming" in relation to social-spatial and material-express alignments. Hence, methodological frameworks can also run the risk of reductionism. In a sense, focusing on the production of "numerical knowledge" and attempts to quantify some of the unquantifiable concepts can be considered as a reductionist approach in urban studies that often overlooks the complexity of place as a socio-spatial assemblage. In effect, to explore how a place works requires a deep understanding of its socio-political processes in relation to the spatial structures. As discussed earlier in the paper, since assemblage thinking focuses on the relations, an urban 
assemblage cannot simply be reduced to its parts. That is why "extensive” properties, such as height, coverage, and length, cannot necessarily predict "intensive" properties, such as "atmosphere" and "character".

Assemblage thinking offers a range of twofold concepts that can be used as a theoretical toolkit to understand the underlying processes of continuity and change in the cities. Formal/informal is one of the key twofold conceptions that resonates with a range of other twofold concepts including tree/rhizome, striated/smooth, and hierarchy/network. The formal/informal twofold can elaborate on the ways in which the "strategies" of the state collide with the everyday "tactics" of the citizens. Moreover, assemblage thinking has the capacity to explore the in-between conditions where the boundaries between the two ends of a twofold conception are blurry.

Assemblage thinking extends the conception of the "reality" to encompass both the "actual" and the "possible". In other words, "reality" cannot be limited to the study of what is "actual". In a sense, exploring the space of possibilities can become a particular line of inquiry in both theory and practice where design professions can benefit from the process of "design as research" in the city. Moreover, assemblage thinking moves from the analysis of the parts to the exploration of the relations between parts across different scales. In this way, it can be adopted as an effective theoretical lens for understanding generativity, emergence, and complexity where the outcomes are often unpredictable (Kamalipour, 2015; Peimani, 2015). That is indeed a focus on the processes rather than the products. In a sense, it can stimulate a move from a desire to put emphasis on the form to an initiative for exploring the possibilities for incrementalism, adaptation, and temporality in the city.

\section{References}

Acuto, M. (2011). Putting ANTs into the Mille-Feuille. City, 15, 552-562. http://dx.doi.org/10.1080/13604813.2011.609021

Alexander, C. (1964). A City Is Not a Tree. Architectural Forum, 122, 58-61.

Allen, J. (2011). Powerful Assemblages? Area, 43, 154-157. http://dx.doi.org/10.1111/j.1475-4762.2011.01005.x

Anderson, B., \& McFarlane, C. (2011). Assemblage and Geography. Area, 43, 124-127. http://dx.doi.org/10.1111/j.1475-4762.2011.01004.X

Anderson, B., Kearnes, M., McFarlane, C., \& Swanton, D. (2012). On Assemblages and Geography. Dialogues in Human Geography, 2, 171-189. http://dx.doi.org/10.1177/2043820612449261

Angelo, H. (2011). Hard-Wired Experience: Sociomateriality and the Urban Everyday. City, 15, 570-576. http://dx.doi.org/10.1080/13604813.2011.609023

Ballantyne, A. (2007). Deleuze and Guattari for Architects. London: Routledge.

Bell, J. A., \& Colebrook, C. (Eds.). (2009). Deleuze and History. Edinburgh: Edinburgh University Press. http://dx.doi.org/10.3366/edinburgh/9780748636082.001.0001

Bonta, M., \& Protevi, J. (2004). Deleuze and Geophilosophy: A Guide and Glossary. Edinburgh: Edinburgh University Press.

Brenner, N. (2009). What Is Critical Urban Theory? City, 13, 198-207. http://dx.doi.org/10.1080/13604810902996466

Brenner, N., Madden, D. J., \& Wachsmuth, D. (2011). Assemblage Urbanism and the Challenges of Critical Urban Theory. City, 15, 225-240. http://dx.doi.org/10.1080/13604813.2011.568717

Buchanan, I., \& Parr, A. (Eds.) (2006). Deleuze and the Contemporary World. Edinburgh: Edinburgh University Press. http://dx.doi.org/10.3366/edinburgh/9780748623419.001.0001

De Landa, M. (1997). A Thousand Years of Nonlinear History. New York: Zone Books.

De Landa, M. (2000). Deleuze, Diagrams, and the Genesis of Form. Amerikastudien/American Studies, 45, 33-41.

De Landa, M. (2002). Intensive Science and Virtual Philosophy. London; New York: Continuum.

De Landa, M. (2005). Space: Extensive and Intensive, Actual and Virtual. In I. Buchanan, \& G. Lambert (Eds.), Deleuze and Space (pp. 80-88). Edinburgh: Edinburgh University Press. http://dx.doi.org/10.3366/edinburgh/9780748618743.003.0005

De Landa, M. (2006). A New Philosophy of Society: Assemblage Theory and Social Complexity. London; New York: Continuum.

De Landa, M. (2010). Deleuze: History and Science. New York: Atropos.

De Landa, M. (2011). Philosophy and Simulation The Emergence of Synthetic Reason. London: Continuum International Publishing Group.

Deleuze, G., \& Guattari, F. L. (1987). A Thousand Plateaus: Capitalism and Schizophrenia (B. Massumi, Trans.). Minneapolis, MN: University of Minnesota Press.

Dewsbury, J. D. (2011). The Deleuze-Guattarian Assemblage: Plastic Habits. Area, 43, 148-153.

http://dx.doi.org/10.1111/j.1475-4762.2011.01006.x 
Dovey, K. (2010). Becoming Places: Urbanism/Architecture/Identity/Power. London; New York: Routledge.

Dovey, K. (2011). Uprooting Critical Urbanism. City, 15, 347-354. http://dx.doi.org/10.1080/13604813.2011.595109

Eriksson, K. (2005). Foucault, Deleuze, and the Ontology of Networks. The European Legacy, 10, 595-610. http://dx.doi.org/10.1080/10848770500254118

Farías, I. (2010). Introduction: Decentring the Object of Urban Studies. In I. Farías, \& T. Bender (Eds.), Urban Assemblages: How Actor-Network Theory Changes Urban Studies (pp. 1-24). London; New York: Routledge.

Farías, I. (2011). The Politics of Urban Assemblages. City, 15, 365-374. http://dx.doi.org/10.1080/13604813.2011.595110

Foucault, M. (1980). Power/Knowledge: Selected Interviews and Other Writings (C. Gordon, Ed.). New York: Pantheon.

Jacobs, J. (1961). The Death and Life of Great American Cities. New York: Random House.

Kamalipour, H. (2015). Emerging Urbanity: Learning from Informal Settlements as Assemblages of Permanent Temporality. Paper Presented at the Agency/Agents of Urbanity Colloquium, Swiss Federal Institute of Technology (EPFL), Lausanne, 1-2 June 2015.

Kamalipour, H., \& Zaroudi, M. (2014). Sociocultural Context and Vernacular Housing Morphology: A Case Study. Current Urban Studies, 2, 220-232. http://dx.doi.org/10.4236/cus.2014.23022

Kamalipour, H., Faizi, M., \& Memarian, G. (2014). Safe Place by Design: Urban Crime in Relation to Spatiality and Sociality. Current Urban Studies, 2, 152-162. http://dx.doi.org/10.4236/cus.2014.22015

Kamalipour, H., Memarian, G., \& Mousavian, F. (2012). Exploring the Myth of Four in the Persian Vernacular Architecture. Paper Presented at the IASTE 2012: The Myth of Tradition, Portland, 4-7 October 2012.

Kamalipour, H., Yeganeh, A. J., \& Alalhesabi, M. (2012). Predictors of Place Attachment in Urban Residential Environments: A Residential Complex Case Study. Procedia-Social and Behavioral Sciences, 35, 459-467.

http://dx.doi.org/10.1016/j.sbspro.2012.02.111

Legg, S. (2011). Assemblage/Apparatus: Using Deleuze and Foucault. Area, 43, 128-133. http://dx.doi.org/10.1111/j.1475-4762.2011.01010.x

May, T. (2005). Gilles Deleuze: An Introduction. Cambridge, UK: Cambridge University Press. http://dx.doi.org/10.1017/CBO9781139165419

McCann, E. (2011). Veritable Inventions: Cities, Policies and Assemblage. Area, 43, 143-147. http://dx.doi.org/10.1017/CBO9781139165419

McCann, E., Roy, A., \& Ward, K. (2013). Assembling/Worlding Cities. Urban Geography, 34, 581-589. http://dx.doi.org/10.1080/02723638.2013.793905

McFarlane, C. (2011a). Assemblage and Critical Urbanism. City, 15, 204-224. http://dx.doi.org/10.1080/13604813.2011.568715

McFarlane, C. (2011b). The City as Assemblage: Dwelling and Urban Space. Environment and Planning D: Society and Space, 29, 649-671. http://dx.doi.org/10.1068/d4710

Peimani, N. (2015). Assemblages of Transit Morphologies: Emergent Urbanity in Tehran. Paper Presented at the Agency/Agents of Urbanity Colloquium, Swiss Federal Institute of Technology (EPFL), Lausanne, 1-2 June 2015.

Phillips, J. (2006). Agencement/Assemblage. Theory, Culture \& Society, 23, 108-109. http://dx.doi.org/10.1177/026327640602300219

Simone, A. (2011). The Surfacing of Urban Life: A Response to Colin McFarlane and Neil Brenner, David Madden and David Wachsmuth. City, 15, 355-364. http://dx.doi.org/10.1080/13604813.2011.595108

Tonkiss, F. (2011). Template Urbanism: Four Points about Assemblage. City, 15, 584-588. http://dx.doi.org/10.1080/13604813.2011.609026

Wise, J. M. (2005). Assemblage. In C. J. Stivale (Ed.), Gilles Deleuze: Key Concepts (pp. 77-87). Montreal; Ithaca: McGillQueen's University Press. 